\title{
Biopulping Of Bagasse Using Different Types Of White Rot Fungi and Different Incubation Times
}

\author{
Angelin Marhavyna Cristy, Aris Mumpuni, Nuniek Ina Ratnaningtyas \\ Faculty of Biology, Jenderal Soedirman University, Jalan dr. Suparno no. 63 Purwokerto 53122 \\ Jenderal Soedirman University, Jalan dr. Suparno no. 61 Purwokerto 53122 \\ email: angelangelina202@gmail.com
}

\begin{abstract}
Rekam Jejak Artikel:
Diterima : 30/08/2019

Disetujui : 19/11/2020

\section{Abstract}

Bagasse is fibrous residue that remains after the sugarcane is crushed to extract it's juice. It mostly consists of lignocellulosic materials that may provide material for paper production through biopulping process. White rot fungi (WRF) is producers of extracellular ligninolytic enzymes that has the capability to mineralize lignin compounds. Three types of white rot fungi that were used in this study are Phanerochaete chrysosporium, Pleurotus ostreatus and Schizophyllum commune. Each of it was inoculated on bagasse substrate within 0,15 , and 30 days of incubation. This study was aimed to know the effect of interaction between white rot fungi and incubation time in the biopulping process and to investigate the most appropriate fungus and incubation time to produce good material for paper making obtained from sugarcane bagasse. The experimental design was done by using Completely Randomized Design (CRD) with a factorial pattern in two factors and analyzed by using Analysis of Variance (ANNOVA) then followed by Duncan's Multiple Range Test (DMRT) on highly different significance effect of the treatment. The result of this study showed that $\mathrm{S}$. commune is the most effective fungi to degrade highly lignin content $(17.38 \%$ to $8.88 \%)$ at 30 days of incubation, while $P$. chrysosporium is the most effective fungi to lowering cellulose content in small amount $(23.64 \%$ to $19.38 \%$ ) during 30 days of incubation.

Keywords: White Rot Fungi (WRF); bagasse; biopulping; Phanerochaete chrysosporium; Schizophyllum commune.
\end{abstract}

\section{INTRODUCTION}

Central and East Java are centers of cane sugar industry in Indonesia because the area of sugarcane plantation in this area is wide. According to Badan Pusat Statistik (2015), the largest sugarcane production derived from East Java Province which is amounted to 1.24 million tons, whereas the sugarcane production that is located in Central Java is amounted to 206.25 thousand tons. The production of sugar cane plantation always remains sugarcane leaves and bagasse in large amount (Khuluq, 2012).

Bagasse is the fibrous residue that remains after the sugarcane is extracted into it's juice and mostly contains of lignocellulose compound such as lignin (13-22\%), cellulose (26-43\%), hemicellulose (17-23\%) and pentosan (20-33\%) (Johnson, \& Vikram, 2012). The utilization of bagasse will provide more benefits in reducing deforestation rather and can be used as a raw materials for pulp and paper making (Al-Sulaimani $\&$ Dwivedi, 2017). Bagasse is derived from the sugar cane plant (Saccharum officinarum) which grows in tropical and sub tropical areas. It is a member of family Gramineae which has morphology of stem height approximately 3-5 m, does not have branches and grows upright. The fiber of bagasse is insoluble in water and consists mainly of cellulose, pentosan and lignin (Rulianah et al., 2017). The process of degrading lignin is necessary to do by lignin-degrading fungi before making pulp through biopulping process.

Biopulping is the treatment of lignocellulose degradation with a fungus which have ligninolytic enzyme and the subsequent processing of material can be done through mechanical or chemical 
pulping (Saad et al., 2008). The best treatment of the biopulping process is treatment which results in a high decrease of lignin content but minimal loss of cellulose content. The concept of biopulping is based on the ability of fungi to colonize and degrade lignin selectively in wood thereby remains cellulose relatively intact (Singhal et al., 2015). One part of biopulping is biodelignification. Biodelignification is a process which use biological agents or organisms that are capable of releasing cellulosic fibers from a lignin bonds by its natural ability (Chang \& Miles, 1989).

White rot fungi (WRF) which is classified in the Basidiomycota group is the most effective organisms that able to degrade the whole wood components due to the secretion of extracellular ligninolytic enzymes such as lignin peroxidase (LiP), manganese dependent peroxidase triplicate $(\mathrm{MnP})$, and laccase that has the capability to mineralize lignin and phenolic organic substrates. According to Musa et al. (2012), White rot fungi will break down lignin completely into water $\left(\mathrm{H}_{2} \mathrm{O}\right)$ and carbon dioxide $\left(\mathrm{CO}_{2}\right)$ At the end process of lignin degrading, they will leave decayed wood by whitish in color and fibrous in texture. They are preferentially attacking lignin more readily and then leaving enriched cellulose (Rodríguez-Couto, 2017).

Three white rot fungi that have been employed are Pleurotus ostreatus, Schizophyllum commune and Schizophyllum commune which are classified in the Phylum Basidiomycota. The activity of those fungal may interact with the time of incubation to biodelignify bagasse by the lignocellulolytic properties of their ezyme. The incubation time is expected affect the ability of several white rot fungi to degrade lignin in bagasse. This situation can occurs because the incubation time will give the opportunity to fungi to use organic materials as an energy source and carbon source to form new cells and produce ligninbreaking enzymes (Chang \& Miles, 1989).

Biopulping process requires longer incubation time for growth of fungal biomass and delignification. However, the longer the incubation time the higher losses of bagasse chemical components such as extractive substances, lignin, cellulose and hemicellulose can be occured. It may be caused by differences capability of each fungi in the production of enzyme to degrade the substrate.

According to Musa et al. (2012), P. chrysosporium fungi is the most effective that exist in wood and produce three extracellular enzymes of LiP, MnP and Lac. It has an ability to degrade lignin component first then followed by degrading cellulose component.

The objectives of this study are (1) to know the effect of interaction between white rot fungi and incubation time in the biopulping process, and (2) and to investigate the most appropriate fungus and incubation time to produce good material for paper making from sugarcane bagasse.

\section{MATERIAL AND METHODS}

\section{Materials}

The materials were used are isolate of Pleurotus ostreatus from Agro Jamur Pabuwaran collection, isolates of Phanerochaete chrysosporium and Schizophyllum commune from Mycology and Phytophatology Laboratory of Biology Faculty collection, bagasse from cane sugar factory of PT. Gendhis Multi Manis Blora, Potato Dextrose Agar (PDA), distilled water, alcohol 70\%, sorghum, spiritus, plastic wrapper, aluminium foil, cotton.

\section{Research Design}

The experiment was conducted using Completely Randomized Design (CRD) with a factorial pattern in two factors. The two factors are three types of white rot fungi and incubation times of 0,15 , and 30 days. Three types of white rot 
BioEksakta: Jurnal Ilmiah Biologi Unsoed

Volume 2, Nomor 3 (2020): 403 - 410

fungi that were used are Phanerochaete chrysosporium, Pleurotus ostreatus and Schizophyllum commune. The treatments were carried out as follows (P1W0) the treatments of $P$. chrysosporium at 0 day of incubation, (P1W1) the treatments of $P$. chrysosporium at 15 days of incubation, (P1W2) the treatments of $P$. chrysosporium at 30 days of incubation, (P2W0) the treatments of $P$. ostreatus at 0 day of incubation, (P2W1) the treatments of $P$. ostreatus at 15 day of incubation, (P2W2) the treatments of $P$. ostreatus at 30 days of incubation, (S3W0) the treatments of $S$. commune at 0 day of incubation, (S3W1) the treatments of S. commune at 15 days of incubation, (S3W2) the treatments of $S$. commune at 30 days of incubation. Each treatment had 3 replication and obtained 27 experimental units. All of the results have been analyzed by using Analysis of Variance (ANNOVA) then followed by Duncan's Multiple Range Test (DMRT) on highly different significance effect of the treatment.

\section{Procedures}

\section{Sample Preparation}

Bagasse sample was strained through a muslin cloth to remove from dirt and then dried under sunlight for approximately 5 hours in a day until dry. Further, the bagasse was collected into a cloth carry bag.

\section{Fungal Spawn Inoculum Preparation (Kusnadi \& Yayan, 2003, modified)}

Sorghum as much as $5 \mathrm{~kg}$ was prepared. It was soaked in water for approximately 2 hours. Floating dirt and seeds were removed. The sorghum was drained and then steamed with water until the seeds burst at one point. After steaming process, it was cooled for several minute and drained. $50 \mathrm{~g} \mathrm{CaCO}_{3}$ and $25 \mathrm{~g}$ dextrose were added and mixed evenly with the sorghum. Then, all of it was evenly mixed. The sorghum was filled into 350 ml glass bottles until 2/3 bottle size. The bottles were covered by using cotton wool plug and then sterilized with autoclave at $121^{\circ} \mathrm{C}$ for 1 hours and allowed it to released the condensed water of steam.

\section{Fungal Inoculation on Sorghum Media (Rachel \& Adebolu, 2014, modified)}

The pure culture of P.chrysosporium, P. ostreatus, and S. commune in PDA medium prepared. The inoculation was done in triplicates for each of fungal spawn. The inoculation process was done by using sterilized cork borer (which has a diameter $0.5 \mathrm{~cm}$ ) to cut the agar media that containing the pure culture of the fungi. Each pure cultures was taken as much as 5 plug and then transferred to the glass bottle that contains the sorghum aseptically inside the LAF. Then, it was incubated at room temperature for 1 month until the mycelium are fully covered the sorghum medium.

\section{Preparation of Bagasse Substrate (Sidana \& Umar, 2014, modified)}

Bagasse which has been processed was take out from cloth carry bag, drained and then put it into a container. The distilled water as much as $1 \mathrm{~L}$ and bagasse as much as $1 \mathrm{~kg}$ were prepared. The distilled water was added slowly and mixed evenly with $1 \mathrm{~kg}$ bagasse in the container. The water content of bagasse was set up until $10 \%$. After the bagasse substrate had been evenly mixed, $200 \mathrm{~g}$ of bagasse was weighed by using analytical scale and then filled it into $25 \times 20 \times 0.008 \mathrm{~cm}$ poly propylene plastic bags. The preparation was done in three replications of each fungal isolate. All of baglogs were carried out with the process of compaction, then baglog which have been densed on the top of plastic bag was given a paralon ring and corked with cotton. The baglogs were sterilized in autoclave for 2 hours at temperature $121^{\circ} \mathrm{C}$. The media that have been sterilized was cooled for 12 hours before inoculation. 


\section{Fungal Inoculation on Bagasse substrate (Suryani \& Hilda, 2017, modified)}

The isolates of three types of white rot fungi (P. ostreatus, P. chrysosporium, and S. commune) from sorghum media was taken $10 \%$ from the weight of bagasse substrate medium. The inoculation process was done by make a deep hole approximately $2 \mathrm{~cm}$ in the middle of the baglog media by using sterilized wooden sticks. Then, the fungal spawn put into polybags aseptically by using spatula. Further, it was incubated in the room temperature with the incubation time of 0,15 , and 30 days.

\section{Analysis of Lignin and Cellulose content (Chesson, 1981)}

Analysis of lignin and cellulose before and after incubation time $(0,15$, and 30 days) was done by following the Chesson method

\section{Analysis Data (Weber \& Skillings, 2000, modified)}

The quantitative data of the lignin and cellulose contents at the beginning and the end of treatment were analyzed by using analysis of variance (ANNOVA) with 5\% significant. Then it was followed by Duncan's Multiple Range Test (DMRT) to determine the difference between each treatment.

\section{RESULT AND DISCUSSION}

\section{Lignin Contents}

The content of lignin on bagasse substrate can be degraded by using the treatment of Phanerochaete chrysosporium, Pleurotus ostreatus, and Schizophyllum commune during biodelignification process. The measurement of lignin content was done to evaluate the effect of type of white rot fungi and incubation time to the biodelignification processs. The treatments of $S$. commune fungi that incubated at 30 days of incubation had the lowest percentage of lignin content on the bagasse substrate. The data of lignin content on bagasse substrate by each type of white rot fungi can be showed

in Figure 1.

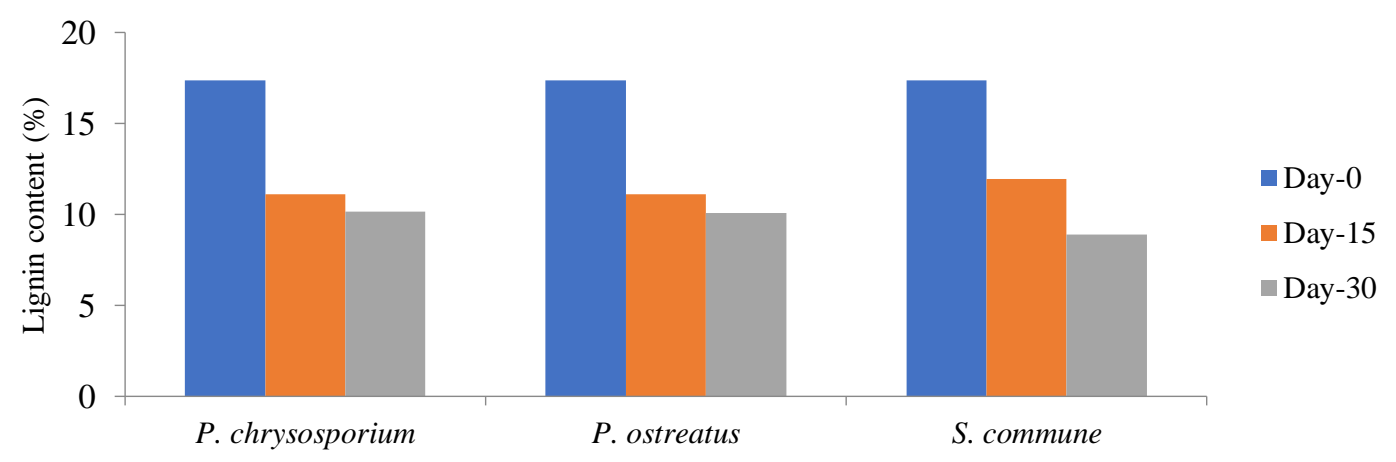

Figure 1. Lignin content on bagasse substrate by each type of white rot fungi at different incubation time

Figure 1. showed the content of lignin in all treatments at incubation time of 0 day was $17.38 \%$. This lignin content can be used as the initial lignin content. The treatments of $S$. commune in 30 days of incubation showed that this fungus was able to degrade the lignin content on bagasse from $17.38 \%$ to $8.88 \%$ (S3W2). While the treatments of $S$. commune at 15 days of incubation was only able to degrade lignin compound from $17.38 \%$ to $11.93 \%$
(S3W1). This result revealed that the most effective treatment showed by the treatment of $S$. commune. Meanwhile, according to Nurika, (2019) $S$. commune also produced similar extracellular enzymes of peroxidase enzymes ( $\mathrm{LiP}$ and $\mathrm{MnP}$ ) and laccases, but the activity of this fungi increased at fourth and fifth week. Based on the result, the lowest reduction of final lignin content was showed by the treatment of $S$. commune. 
Table 1.Duncan's Multiple Range Test (DMRT) on The Interaction between Type of White Rot Fungi and Incubation Time on The Contents of Lignin (\%) in Bagasse Substrate

\begin{tabular}{ll}
\hline Treatment & Averages \\
\hline P1W0 & $17.38 \mathrm{a}$ \\
P1W1 & $11.12 \mathrm{c}$ \\
P1W2 & $10.15 \mathrm{~d}$ \\
P2W0 & $17.38 \mathrm{a}$ \\
P2W1 & $10.07 \mathrm{c}$ \\
P2W2 & $11.17 \mathrm{~d}$ \\
S3W0 & $17.38 \mathrm{a}$ \\
S3W1 & $11.93 \mathrm{~b}$ \\
S3W2 & $8.88 \mathrm{e}$ \\
\hline
\end{tabular}

*Note : The numbers was accompanied by different letters the mean is significant $(p<0.05)$

P1W0 : P. chrysosporium at 0 day of incubation P1W1 : $P$. chrysosporium at 15 days of incubation

P1W2 : $P$. chrysosporium at 30 days of incubation

P2W0 : P. ostretaus at 0 day of incubation

$\mathrm{P} 2 \mathrm{~W} 1 \quad:$. ostreatus at 15 days of incubation

P2W2 : P. ostreatus at 30 days of incubation

S3W0 : $S$. commune at 0 day of incubation

S3W1 : S. commune at 15 days of incubation

S3W2 : S. commune at 30 days of incubation

The DMRT results above showed that the interaction of the three types of white rot fungi and incubation times gave highly significant difference to the lignin content on bagasse substrate. The most effective treatment of the delignification process on bagasse was shown by the inoculation of $S$. commune at 30 days of incubation. The most effective lignin degradation activity in bagasse by $S$. commune is contrary with the statement of S. commune Ramos et al. (2004), who stated that $P$. chrysosporium is the best fungi in the degradation of lignin content on bagasse due to the highest yield production by this fungi in the biomechanical pulping process. But according to the observation result of Herliyana (1997), after 6 weeks of incubation, the inoculation of $S$. commune on wood pulp of Acacia mangium was able to reduce lignin content up to $69.3 \%$ compared to $P$. chrysosporium that can only reduce lignin content $41.8 \%$ on the similar pulp for 30 days of incubation. Actually, $S$. commune was reported as a slow degrader of wood under controlled laboratory conditions, but, if natural conditions are provided, it degrades wood faster like other white rot fungi (Koyani et al., 2014).

The least average reduction of lignin content can be showed by the treatment of $P$. chyrsosporium fungi. In this study, the growth of $P$. chrysosporium fungi was slower compared to other fungi, $S$. commune and $P$. ostreatus fungi. According to Herliyana (1997), this was thought due to several factors, such as the origin of isolates and the media growth that were used.

\section{Cellulose Content}

The content of cellulose on bagasse substrate also can be degraded by using the treatment of $P$. chrysosporium, P. ostreatus, and $S$. commune fungi during the biodelignification process. The measurement of cellulose content was done to evaluate the effect of type of white rot fungi and incubation time to the biodelignification procees.

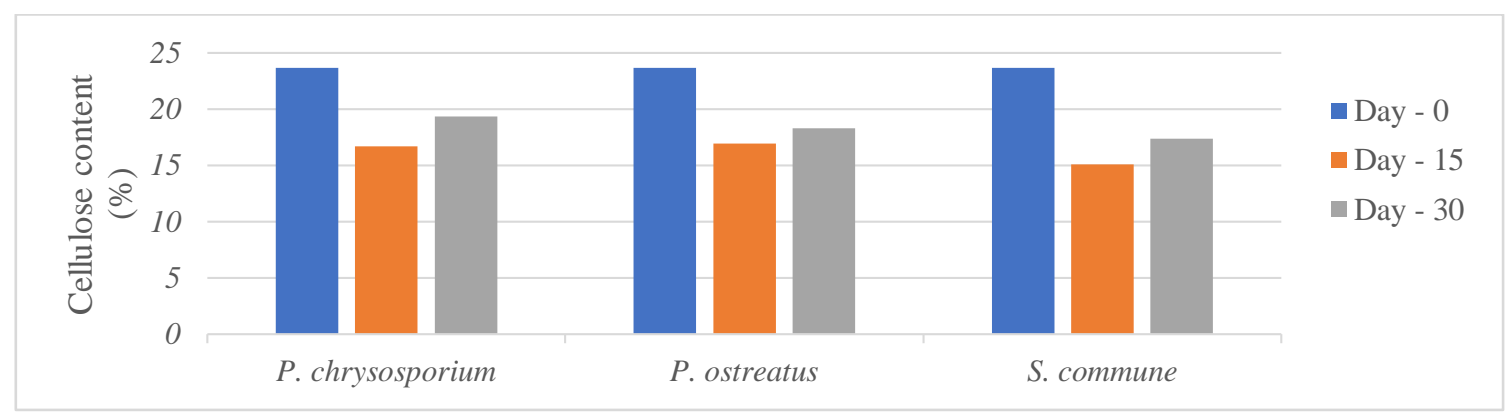

Figure 2. Cellulose content on bagasse substrate by each type of white rot fungi at different incubation time 
Figure 2. showed the content of cellulose in all treatments at incubation time of 0 day was $23.64 \%$. The highest percentage of cellulose content in the incubation of 0 days due to there were no treatment with the type of WRF. Therefore, this cellulose content can be used as the initial cellulose content.

Table 2. Duncan's Multiple Range Test (DMRT) on The Effect of Interaction between Type of White Rot Fungi and Incubation Time on The Final Cellulose Contents (\%)

\begin{tabular}{cc}
\hline Treatment & Averages \\
\hline P1W0 & $23.64 \mathrm{a}$ \\
P1W1 & $16.69 \mathrm{e}$ \\
P1W2 & $19.35 \mathrm{~b}$ \\
P2W0 & $23.64 \mathrm{a}$ \\
P2W1 & $16.90 \mathrm{de}$ \\
P2W2 & $18.27 \mathrm{c}$ \\
S3W0 & $23.64 \mathrm{a}$ \\
S3W1 & $15.09 \mathrm{f}$ \\
S3W2 & $17.38 \mathrm{~d}$
\end{tabular}

* Note : The numbers was accompanied by different letters the mean is significant $(\mathrm{p}<0.05)$

P1WO : P. chrysosporium delignification on bagasse substrate at 0 day of incubation

P1W1 : P. chrysosporium delignification on bagasse substrate at 15 days of incubation

P1W2 : P. chrysosporium delignification on bagasse substrate at 30 days of incubation

P2W0 : P. ostreatus delignification on bagasse substrate at 0 day of incubation

P2W1 : P. ostreatus delignification on bagasse substrate at 15 days of incubation

P2W2 : P. ostreatus delignification on bagasse substrate at 30 days of incubation

S3W0 : S. commune delignification on bagasse substrate at 0 day of incubation

S3W1 : S. commune delignification on bagasse substrate at 15 days of incubation

S3W2 : S. commune delignification on bagasse substrate at 30 days of incubation

Table 2. showed the result of DMRT test. The treatment between white rot fungi and incubation time gave a highly significant difference to the reduction of cellulose content in bagasse substrate. The most effective treatment of cellulose degradation process was shown by $P$. chrysosporium at the incubation time of 30 days (P1W2) with the highest average of final cellulose content $19.35 \%$ followed by $P$. ostreatus fungi at incubation time of 30 days (P2W2) with an average final cellulose content of $18.27 \%$ and the least average percentage of final cellulose content found in the treatment of $S$. commune fungi at incubation time of 30 days with an average cellulose content reduction $17.38 \% \quad(\mathrm{~S} 3 \mathrm{~W} 2)$. These results in accordance to Fadilah et al. (2008), states that in addition to the ability of produced the ligninase enzyme, $P$. chrysosporium fungi also produced cellulase and hemicellulose enzymes.

According to Kempken (2012), $\quad P$. chrysosporium is a selective white rot fungi that appears to be selective in their degradation of lignocellulose, which mainly degrading lignin and hemicellulose but leaving a major part of cellulose undegraded. Besides producing ligninase enzyme, P. chrysosporium also produced cellulase and hemicellulase enzymes. According to Rulianah et al. (2017), the cellulase enzyme that produced by $P$. chyrsosporium had the highest activity in temperature 25 to $40^{\circ} \mathrm{C}$.

According to Nadir et al. (2019), P. ostreatus fungi was able to degrade all the lignocellulose components of lignin (11.1\%), xylan $(15.7 \%)$ and glucan $(8.4 \%)$ on the bagasse substrate at 60 days of incubation. This fungi can be considered as a non-selective delignifier because it concurrently breaks down lignin and structural carbohydrate. According to Gunawan et al. (2017) xylan and glucan are the main hemicellulose in the primary cell wall of hardwood plant.

Treatments of $S$. commune in different incubation times (15 and 30 days of incubation) showed a significant increase to the final cellulose content, but the average percentage of final cellulose content was not greater than final cellulose concentration which was resulted by the treatments of $P$. chrysosporium and $P$. ostreatus fungi. According to Maryam (2011), S. commune 
fungi is one type of non-selective fungi which had fast growth and can causes a weathering and wood discoloration. This fungus also had the enzyme of selobiohydrolase and endo1.4 $\beta$-glucanase for cellulose degradation.

According to Rodríguez-Couto (2017), during pulp and paper production, it is necessary to separate the cellulose fibers from lignin. Biopulping is a good treatment for wood chips processing with ligninolytic fungi prior to conventional pulping methods either mechanical or chemical pulping methods. The benefits of biopulping in the production of paper were environmentally-friendly, cheap cost and can reduce not only energy consumption but also the utilization of chemicals.

\section{CONCLUSION}

The interaction effect of 3 types of white rot fungi and incubation time has a highly significant effect on the final lignin content of bagasse substrate. The most effective interaction to degrade lignin showed in the treatment of S. commune at 30 days of incubation with the lowest average of final lignin content as $8.88 \%$. While, the most effective interaction that resist cellulose content remained high showed by the treatment of $P$. chrysosporium in 30 days of incubation with the highest average of final cellulose contents as $19.38 \%$. S. commune and $P$. chrysosporium are the most appropriate fungus which are effective in the biodelignification process of bagasse within 30 days of incubation time.

\section{REFERENCE}

Al-Sulaimani, K., \& Priy, B. D. 2017. Production Of Handmade Papers From Sugar Cane Bagasse And Banana Fibers In Oman. International Journal of Students' Research In Technology \& Management, 5(3): 16-20.

Badan Pusat Statistik. 2015. Statistik Tebu Indonesia 2015. Jakarta: Badan Pusat Statistik Indonesia.
Chang, S.T. \& P.G. Miles., 1989. Edible Mushroom and Their Cultivation. Florida : CRC Press, Inc., Boca raton Florida.

Chesson, A., 1981. Effects of sodium hydroxide on cereal straws in relation to the enhanced degradation of structural polysaccharides by rumen microorganisms. Journal Sci. Food Agric, 32: 745-758.

Johnson, F. X., \& Vikram, S. 2012. Bioenergy For Sustainable Development And International Competitiveness: The Role of Sugarcane In Africa. New York: Routledge Publisher.

Khuluq, A. D. 2012. Potensi Pemanfaatan Limbah Tebu Sebagai Pakan Fermentasi Probiotik. Buletin Tanaman Tembakau, Serat \& Minyak Industri, 4(1): 37-45.

Komalasari, K. 2009. Pengaruh perbandingan volume darah dan lisis buffer serta kecepatan sentrifugasi terhadap kualitas produk DNA pada sapi Frensian Holstein (FH). Skripsi. Institut Pertanian Bogor. Bogor.

Musa, B. H., Edy, B. M., \& Nelly, A. 2012. Wood Rot Fungi Identification on Dead Wood Biodelignification Process in Taman Hutan Raya Bukit Barisan, Karo District. Jurnal $U S U, 1(2): 1-7$.

Nuryadi, W., Anna, R., \& Istiana, P. 2016. Isolasi dan Identifikasi Kapang Endofit dari Pohon Sengon Provenan Kepulauan Solomon Berdasarkan Morfologi dan Molekuler (Analisis rDNA ITS (Internal Transcribed Spacer). Jurnal Biologi. 5(6): 15-26.

Okane, I., Nakagiri, A., Ito, T. 1998. Endophytic fungi in leaves of ericaceous plants. Can $J$ Bot. 76 (4): 657-663.

Paul, C. N. and Yu, H. S. 2008. Two Species of Endophytic Cladosporium in Pine Trees in Korea. Mycobiology. 36(4): 211-216.

Rodríguez-Couto, S. 2017. Industrial and environmental applications of white-rot fungi. Mycosphere, 8(3): 456-466.

Rulianah, S., Irfin, S., Mufid, Prayitno. 2017. Produksi Crude Selulase dari Bahan Baku Ampas Tebu Menggunakan Kapang Phanerochaete chrysosporium. Jurnal Teknik Kimia dan Lingkungan, 1(1): 17-27.

Saad, M. B.W., Oliveira, L.R.M., Cândido, R.G., Quintana, G., Rocha, G.J.M., \& Gonçalves, A.R., 2008. Preliminary studies on fungal treatment of sugarcane straw for organosolv pulping. Enzyme and Microbial Technology, 43 (2): 220-225. 
Singhal, A., Prashant, K. J., Indu, S. T. 2015. Biopulping of bagasse by Cryptococcus albidus under partially sterilized conditions. International Biodeterioration \& Biodegradation, 97: 143-150.

Sahashi, N., Kubono, T., Miyasawa, Y., and Ito, S. 1999. Temporal variations in isolation frequency of endophytic fungi of Japanese beech. Can. J. Bot. 77: 192-202

Song Z., Kennedy G. P., Liew J. F., and Schilling S. J. 2016. Functional Ecology: Fungal Endophyte as Priority Colonizers initiating Wood Decomposition. UK: John wiley \& Sonts.
Tan and Zou. 2001. Endophytes: A Rich Source of Functional Metabolites. Nat. Prod. Rep. 18: 448-459.

Wardani, M. T., Kusdiyantini, E., Budiharjo A. 2017. Identifikasi Isolat Monascus Sp. Hasil Isolasi Angkak Berdasarkan Gen Internal Transcribed Spacer (ITS) Dan Pengukuran Kandungan Pigmen. Jurnal Biologi, 6(2): 34-40.

Widowati, T., Bustanussalam, Harmastini, S., and Partomuan, S. 2016. Isolasi dan Identifikasi Kapang Endofit dari Tanaman Kunyit (Curcuma longa L.) Sebagai Penghasil Antioksidan. Biopropal Industri, 7(1): 7-16. 